6) F. Sutton, “Volumetric Analysis", 12 th Ed., 263; P. Blakiston's Son \& Co., Inc., Philadelphia (1935).

7) A. F. Joseph, J. Soc. Chem. Ind., 29, 187 (1910).

8) I. M. Kolthoff, Pharm. Weekbl., 56, 7, 572, 1565, (1919) ; 58, 1510 (1921) ; Chem. Weekbl., 17, 82 (1920) ; Z. anal. Chem., 60, 338, 341 (1921) ; "Volumetric 'Analysis", II, 422 (1929), or "Die Mass Analyse ", 455 (1931).

9) K. Böttger and W. Böttqer, Z. anal. Chem., 70, 209, 214 (1927).

10) E. C. Gray, J. Chem. Soc., I, 35 (1929).

11) E. H.Swift, J. Am. Chem. Soc., 51, 2682 (1929).

12) A. V. Filosofov and S. Melnik, J.Applied Chem. (U. S.S.R.) , 5, 219 (1932).

13) H. A. Fales, "Inorganic Qualitative Analysis ", 291, The Century Co., New York, (1925) ; J. H. Blackwood and J.D. Stirling, Biochem. J., 26, 353 (1932)
J. B. Termansen, Arch. Pharm. Chemi., 52, 387 (1945)；池上・守田, 八幡制鉄所目発研究, 第 8 号B般 (1949).

14) W.C. Bray and H. E. Miller, J.Am. Chem. Soc., 46, 2204 (1924) ; S. Popoff and J. L. Whitman, J. Am. Chem. Soc., 47, 2259 (1925) ; H. Ditz, Z. anal. chem., 72, 360 (1927) ; M. Böttger, Z. anal. Chem., 72, 367 (1927) ; 9) ; S. Popoff and A. H. Kunz, J. Am. Chem. Soc., 51, 1307 (1929) ; F.L.Hahn, $Z$. ànal. Chem., 73, 412 (1928).

15) B. Kohler, Chem. Listy 14, 137, 195 (1920); P. Putzeys, Ann. Soc. Sci. Bruxelles, [i] 47 B, 159 (1927).

16) R. V.Teis, J. Gen.Chem. (U.S.S.R.) 4, 364(1934); J. Renaudin and M. Renaudin, J. Pharm. Chim., 20, 516 (1934).

\title{
（210） $\mathrm{NH}_{3}-\mathrm{SO}_{3}$ 系無水反応に関する研究（第 1 報）
}

\section{スルファミン酸の一新製造法}

\author{
內田章五・伊藤幸夫
}

\section{1. 緒言}

新工業藥品スルファミン酸 $\left(\mathrm{HSO}_{3} \mathrm{NH}_{2}\right)$ は既にアメリカでは大 規慔に生產され固形强酸として或は有機合成に或は防火剤，農樂 の原料として相当厝範囲に利用されている。製造方法は P. Bau mgarten'1) 及び M.E. Cupery²)によつて提案された尿素に発煙硫 酸を作用する方法が行われている。著者等はこれを $\mathrm{NH}_{3}-\mathrm{SO}_{3}$ 系 無水反応を利用する一例として更に粗原料である $\mathrm{NH}_{3}$ と $\mathrm{SO}_{3}$ とから直接合成することを企てたが幸い工業的新製法を案出し得 た。これは既に工菜化学会第 44 年会 (昭和 16 年 4 月) 飞発表 したところであるが，戰争のため研究す中絕され発表が幄延して いた。 $\mathrm{NH}_{3}, \mathrm{SO}_{3}$ の反応はH. Rose ${ }^{3)}$ を始めとして E. Berglund4), E. Divers, 垪和り等によつて研究が行われたが，この反応をスル フォミン酸の工業的製造に利用しょうとの企のあつたことは未だ 聞かない。著者等は $\mathrm{NH}_{3}$ と $\mathrm{SO}_{3}$ とをガス狀で無水反広を行か せイミドスルフォン酸アンモニウム，アミドスルフォン酸アンモ こウムの混合物を造り，これを硫酸で加水分解，鉷硫酸中よりス ルファミン酸を完全に析出せしめて濾別，母液は硫酸フンモニウ ムの硫酸溶液故，アンモニアを飽充せしめて硫酸アンモニウムと して回收する方法を確立した。

\section{2. $\mathrm{NH}_{3}-\mathrm{SO}_{3}$ 間の無水反応}

$\mathrm{NH}_{3}$ と $\mathrm{SO}_{3}$ を氣狀で $\mathrm{NH}_{3}$ 過剩のすとに反応せしめると，粉 狀及熔融㹜の反底生成物を生ずる。その主成分は前者は $\left(\mathrm{NH}_{4}-\right.$
$\left.\mathrm{SO}_{3}\right)_{2} \mathrm{~N} \cdot \mathrm{NH}_{4}$, 後者は $\left(\mathrm{NH}_{4} \mathrm{SO}_{3}\right)_{2} \mathrm{NH}$ であつて, 生成反応は $4 \mathrm{NH}_{3}+2 \mathrm{SO}_{3}=\left(\mathrm{NH}_{4} \mathrm{SO}_{3}\right)_{2} \mathrm{~N} \cdot \mathrm{NH}_{4}, 3 \mathrm{NH}_{3}+2 \mathrm{SO}_{3}=\left(\mathrm{NH}_{4} \mathrm{SO}_{3}\right)_{2} \mathrm{NH}$ $2 \mathrm{NH}_{3}+\mathrm{SO}_{3}=\mathrm{NH}_{4} \mathrm{SO}_{3} \mathrm{NH}_{2}$ 等であると考えられている。

著者等は重々の謴度の $\mathrm{SO}_{3}$ に $\mathrm{NH}_{3}$ を氣狀で反応させて各條 件下における反応生成物の生成量，性賀等をしらべた。

実驗方法 垁驗裝置は第 1 四に示した。 $\mathrm{SO}_{3}$ の供給系と $\mathrm{NH}_{3}$ の供給禾, 反応管, 反応生成物の捕集器よりなる。 $\mathrm{NH}_{3}$ はボン ブよりフローメーターで計量して送入すればよいが $\mathrm{SO}_{3}$ は常溫で 固体であり腐蝕性が甚しいので一般的な方法で計量して坛入する 第 1 図 $\mathrm{NH}_{3}-\mathrm{SO}_{3}$ 反応裝置

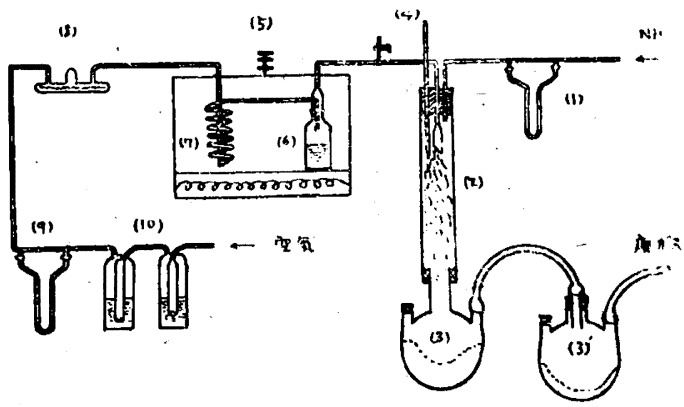

(1)，(9) フローメーター，(2) 反応管，(3)，(3) 受器, (4) 溫度計, (5) 恒溫案氣浴, (6) $\mathrm{SO}_{3},(7)$ 予热管，(8) 五酸化燐管，(10) 硫酸大乾集旣

ことができない。そこで $\mathrm{SO}_{3}$ を加熱して液体としこれに影燥空 氣を㳒つて $\mathrm{SO}_{3}$ を氣化せしめ空氣と共に反応管へ添入する方法 
をとつた。この際坛入室氣, 溫度, 液体 $\mathrm{SO}_{3}$ の表面樍を一定と すれば大体溜出する $\mathrm{SO}_{3}$ の最が一定となるのでこの量を予じめ

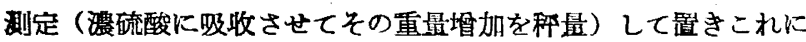
対して $\mathrm{NH}_{3}$ を種々のモル比で送つた。反応管は径 $5 \mathrm{~cm}$ のガラ
ス管を用い反応によつて生じた生成物は下方の受器中に沈積し， 佾飛散したものは次の受器で捕集しろる樣にした。

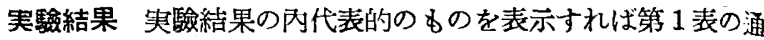
りである。

第 1 表 $\mathrm{NH}_{3}-\mathrm{SO}_{3}$ 間無水反底の实驗結喿

\begin{tabular}{|c|c|c|c|c|c|c|c|c|c|c|c|}
\hline \multirow[b]{2}{*}{$\begin{array}{l}\text { 实 驗 } \\
\text { 番 } \\
\text { No. }\end{array}$} & & 区 & 応 & 保 & 件 & & \multicolumn{3}{|c|}{ 反応生成物の量 } & \multicolumn{2}{|c|}{ 反芯生成物の性狀 } \\
\hline & $\begin{array}{l}\text { 揆入 } \mathrm{SO}_{3} \\
\text { ガス濃度 } \\
\text { (1) \% }\end{array}$ & $\begin{array}{l}\mathrm{SO}_{3} \text { 送入 } \\
\text { 量 }(2) \\
\mathrm{cc} / \mathrm{min}\end{array}$ & $\begin{array}{l}\mathrm{NH}_{3} \text { 䢪入 } \\
\text { 量 (3) } \\
\mathrm{cc} / \mathrm{min}\end{array}$ & $\begin{array}{c}\mathrm{NH}_{3} / \mathrm{SO}_{3} \\
(4) \\
\text { (mol. 比) }\end{array}$ & $\begin{array}{c}\text { 反応溫度 } \\
\text { ( } 5 \text { ) } \\
{ }^{\circ} \mathrm{C}\end{array}$ & $\begin{array}{c}\text { 反㡴時閌 } \\
(6) \\
-\min \end{array}$ & $\begin{array}{c}\text { 全捕策舀 } \\
(7) \\
\text { ( } 7)\end{array}$ & $\begin{array}{c}\text { 粉 }{ }^{\text {狀 }} \\
(8)^{g}\end{array}$ & $\begin{array}{c}\text { 熔 融 状 } \\
(9) \\
\mathrm{g}\end{array}$ & $\begin{array}{c}\text { 莃壆 队 } \\
\mathrm{NH}_{3} \mathrm{SO}_{3} \\
\text { (10) } \\
\text { (mol. 比) }\end{array}$ & $\begin{array}{l}\text { 粉狀扬 } \\
\text { 心比容 } \\
\text { (11) } \\
\mathrm{cc} / \mathrm{g}\end{array}$ \\
\hline 5 & 96 & 330 & 1000 & 3 & $220 \sim 240$ & 45 & 63 & 25 & 38 & 1.2 & 5 \\
\hline 6 & 69 & 330 & 1000 & 3 & $210 \sim 220$ & 120 & 165 & 81 & 84 & 1.3 & 3 \\
\hline 7 & 53 & 340 & 1000 & 3 & $190 \sim 210$ & 90 & 129 & 77 & 52 & 1.4 & 5 \\
\hline 11 & 46 & 420 & 1000 & 2 & $240 \sim 250$ & 90 & 171 & 126 & 45 & 1.6 & 4 \\
\hline 19 & 21 & 80 & 300 & 4 & $160 \sim 170$ & 60 & 20 & 16 & 4 & 1.7 & 5 \\
\hline 16 & 9 & 14 & 100 & 7 & $55 \sim 65$ & 55 & 3 & 2.5 & 0.5 & 1.7 & 10 \\
\hline 18 & 3 & 14 & 100 & 7 & $50 \sim 60$ & 60 & 4.5 & 4.5 & 0 & 2.0 & 18 \\
\hline
\end{tabular}

表中第 10 㯗の $\mathrm{NH}_{3} / \mathrm{SO}_{3}$ は廃ガス中の $\mathrm{NH}_{3}$ を濃度既知の一 定量の酸に吸收させて測定し, $\mathrm{NH}_{3}$ と $\mathrm{SO}_{3}$ が央際に化合した比 を求ぬたるのである。第 11 欄, 粉狀物のみかけの比容は一定重 量の粉狀反応生成物の容積をメスシリンダーで計つて求めた。

以上の実驗結果より $\mathrm{NH}_{3}$ と $\mathrm{SO}_{3}$ は常溫常压において極めて容 易に瞬間的に反応(発熱反応)することがかかる。この際迕入した $\mathrm{NH}_{3}$ はそのモル比が最高 2 迄は化合するがそれ以上のるのは未 反応のま〉発ガス中に逃れる。從つてこれ等の実驗はすべて $\mathrm{NH}_{3}$ の過剩のるとに行つたるのであるといえる。粉狀物と熔融物との 生成比は $\mathrm{NH}_{3} / \mathrm{SO}_{3}$ の邆入比が同一の場合 $\mathrm{SO}_{3}$ の濃度が小なる 程粉狀物が多く生成し、同一濃度の $\mathrm{SO}_{3}$ K怙いては $\mathrm{NH}_{3}$ の运入 量が小て反応溫度が低い程粉狀物が多く生成寸る傾向がある。粉 狀物のみかけの比容は $\mathrm{SO}_{3}$ の濃度が大体 $15 \%$ 以下になると急激 に增大寸る。

\section{3. 反応生成物の加水分解}

イミドスルフォン酸アンモニウムを加水分解すればスルフォミ ン酸篮を生成するのでこの反応を利用して反応生成物よらスルフ フミン酸の製造を試みた。先ず粉狀反応生成物を稀硫酸で加水分 解し，これに濃硫酸を加えてスルフ、ミン酸の溶解度がほとんど 零となる 70\% の硫酸濃度として生成したスルフ 、ン酸を析出 せしめた。析出物は分析及偏光顯微鏡による結晶光学的諸性算の 检討によりスルファミン酸なることを確認した゚。この際スルフ アミン酸の生成反応は次式によるすのと推定される。

$\left(\mathrm{NH}_{4} \mathrm{SO}_{3}\right)_{2} \mathrm{~N} \cdot \mathrm{NH}_{4}+2 \mathrm{H}_{2} \mathrm{SO}_{4}+\mathrm{H}_{2} \mathrm{O}=\mathrm{HSO}_{3} \mathrm{NH}_{2}+3 \mathrm{NH}_{4} \mathrm{HSO}_{4}$, $\left(\mathrm{NH}_{4} \mathrm{SO}_{3}\right)_{2} \mathrm{NH}+\mathrm{H}_{2} \mathrm{SO}_{4}+\mathrm{H}_{2} \mathrm{O}=\mathrm{HSO}_{3} \mathrm{NH}_{2}+2 \mathrm{NH}_{4} \mathrm{HSO}_{4}$, $\mathrm{NH}_{4} \mathrm{SO}_{3} \mathrm{NH}_{2}+\mathrm{H}_{2} \mathrm{SO}_{4}=\mathrm{HSO}_{3} \mathrm{NH}_{2}+\mathrm{NH}_{4} \mathrm{HSO}_{4}$

こらにスルフ 、ミン酸と同時に生成した $\mathrm{NH}_{4} \mathrm{HSO}_{4}$ は 70\%の 硫酸に対して相当溶けるので溶液中に残存寸る。次に加水分解に 扣ける溫度，分解時間，硫酸洪度等の影響をしらへた。

奏驗方法 約 $40 \%$ の $\mathrm{SO}_{3}$ ガスを $\mathrm{NH}_{3}$ 過剩のもとに反応せ しめてえた粉狀反応生成物を試料とした。この一定量をビーカー に科取し少量の水で溶解させ, 稀硫酸（比重 1.14） $20 \mathrm{cc}$ を加之 て加水分解を行わしめる。後传液中の硫酸濃度が丁度 $70 \%$ にな
る樣に濃硫酸（比重 1.84）を詮算して加之る。(この際発熱する ので水冷して液溫が $70^{\circ} \mathrm{C}$ 以上になら樣注意する)一夜放置後 析出したスルファミン酸は，小型グラスフィルターを用いて路空 ポンプでできるだけ母液と分離し更にアルコール，エーテルで洗 滌し乾燥して科量する。

実驗結果 加水分解に抬ける溫度, 分解時間, 最初に使用寸る 硫酸の濃度等はスルフ 、ミン酸の析出量に殆ど影響のないことを 知つた。師ら試料の水溶液に濃硫酸を加えて硫酸濃度を $70 \%$ と するたシけで極めて簡易に加水分解が行われ，最初汼硫酸を加え て加水分解寸る必要すなく分解は常溫で瞬間的に完結寸る。

次に試料を一旦水溶液とせず直ちに $70 \%$ の硫酸を加えて 樣な結果が得られたので,これについて更に，使用する硫酸の濃 度，量に対する実驗を行つた。実驗結果を示せば第 2 表の通りて ある。

第 2 表 加水分解に使用する硫酸の濃度，量の影警

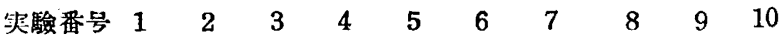
試料探取 $10.0 \quad 10.0 \quad 10.0 \quad 10.0 \quad 10.0 \quad 10.0 \quad 10.0 \quad 10.0 \quad 10.0 \quad 10.0$ 量 $(\mathrm{g})$

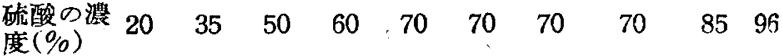

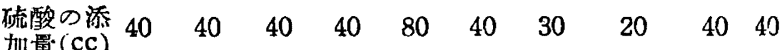

加墨( (CC)

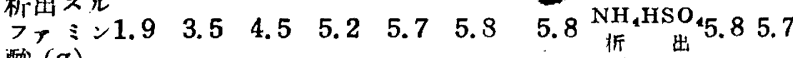
酸 $(\mathrm{g})$

これらより硫酸の瀑度は $70 \%$ 以下ではスルファミン酸の溶解

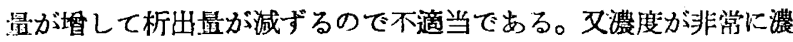
くなると（80\%以上）硫酸を注加する際試料が固化し，一方液の 粘度す增大して析出結晶が非常に微細なすのとなり滤過が困蜼と なる。そこで笑際的には $70 \%$ の硫酸を使用寸るのが最適である と思われる。この際硫酸の添加舅は生成した $\mathrm{NH}_{4} \mathrm{HSO}_{4}$ を完全に 溶しろる量が必要であつて, 上記の実驗結果より, 試料 $10 \mathrm{~g}$ に対 して 70\% の硫酸的 $30 \mathrm{cc}$ が適当であると考えられる。以上の犹 驗は粉状の反応生成物に就て行つたすのであるが塔融狀の反応生 成物についてる，大体同樣にしてスルファミン酸を造ることがて きる。この場合スルファミン酸の生成率は粉狀物より少し惡く, 試料 $10 \mathrm{~g}$ より約 $5 \mathrm{~g}$ のスルフォミン酸がえられる。然し熔融物 は $\mathrm{NH}_{3}$ と $\mathrm{SO}_{3}$ の反応の際反応管につまる恐れがあり, 加水分 
解与る時る一度粉碎して硫酸を添加しなければならないので, 粉 状物が多く生ずるよう操作するのがよい。

\section{4. 新製造法の工業的操作}

この方法によつてスルファミン酸を工業的に製造するには接触 式の硫酸製造裝置を有する硫安工場で硫安の製造と噺せて行らの が最む得策である。その製造工程を図示すれば第2四の如くであ る。

こ১にスルファミン酸を濾別した母液は硫酸アンモニウムのみ を含む 60〜70\% の硫酸溶液となるので加水分解に使用する硫酸 は硫安製造用の硫酸を一㭙転用し分解後再び母液を元に戾すと考 えればよい。このように結局 $\mathrm{NH}_{3}$ と， $\mathrm{SO}_{3}$ よりスルフォミン酸 に変化しなかつたすのは全部硫安として回收し5るので経済的に 製造することができる訳である。

$$
\text { 一引用文献一 }
$$

1) Ber., 62, 1929 (1936):

2) Ind. Eng. Chem., 30, 627 (1938).

3) Pogg. Ann., 32, 81 (1834). その他.

4) Ber., 9, 1896 (1876).

5) 日化, 14, 205 (1895) ; J.Chem. Soc., 61, 948 (1892)

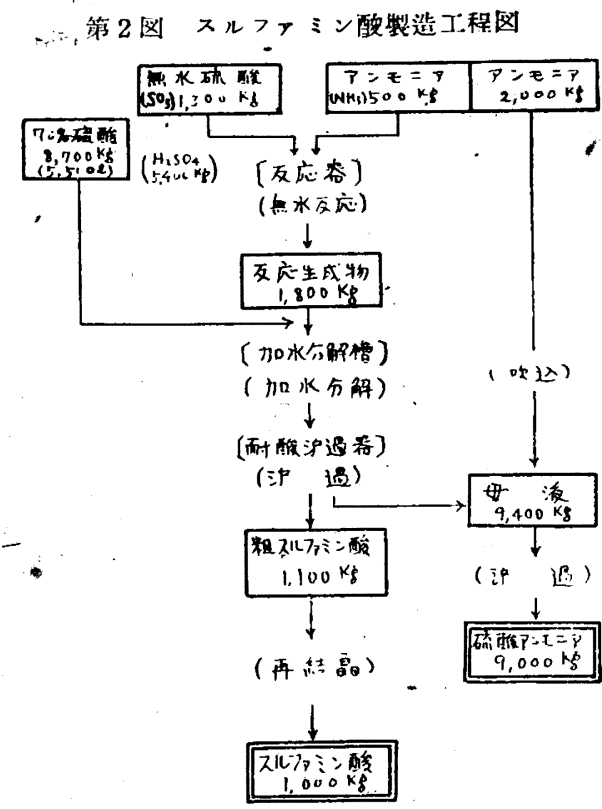

その他.

6) 日化, 63, 504 (1942).

（211）液態アンモニアによる低溫タール処理に関する研究（第 5 報）

濃厚アンモニ゙ア水による抽出にっいて

松木保夫・石田淸春

溶刜精製に怙いて混合溶媒を使用せる場合混合せられる溶媒の 種類により抽出結果に及ぼす選択性に相当顯著なる美異が認めら れ, 桑田1，神力 ${ }^{2}$ 氏等は低溫タール処理を各々フェノール，メ タノールの含水溶隹につき, 天笠氏等》は液安ーフルコール溶媒に よる頁岩油の重賀溜分の抽出につき報告している。

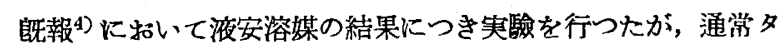
ール中には $0 \sim 3 \%$ 程度の水分が含有されているので含水アンモ
こアによる抽出実驗を行い液安処理の結果と比較した。

\section{実驗及び結果}

既報のピッチ拢き粗中油溜分（沸点範囲 $149 \sim 283^{\circ} \mathrm{C}$ )を從前同 樣の裝置を用い, 同一実驗方法に上り液安の水分含有量 $0 \sim 30 \%$ なる如き濃厚アンモニア水による單一抽出沠に上り $0^{\circ}$ 及び $20^{\circ} \mathrm{C}$ に抬いて抽出を行つた。第1表にその央驗結果の概略を示した。

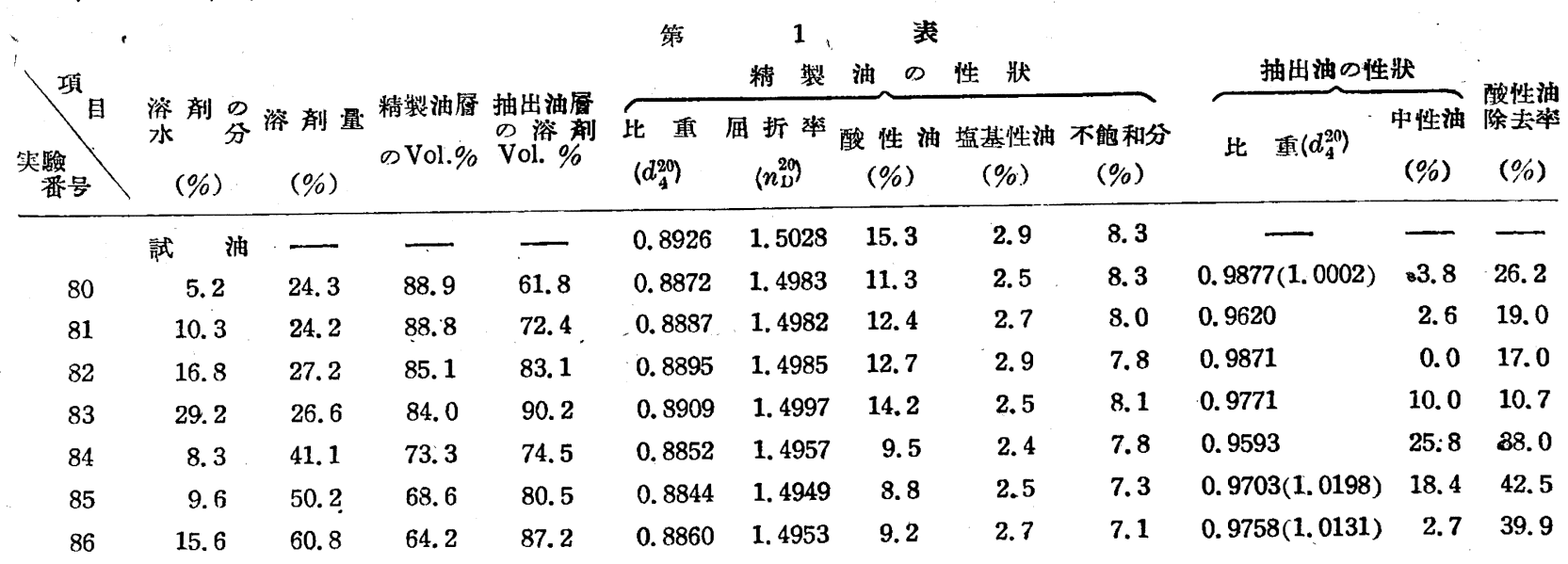

